Review Article

\title{
Sex Hormones and Inflammation Role in Oral Cancer Progression: A Molecular and Biological Point of View
}

\author{
Maria Contaldo (D), ${ }^{1}$ Mariarosaria Boccellino $\mathbb{I D}^{2},{ }^{2}$ Giuseppa Zannini ${ }^{(D)},{ }^{3}$ Antonio Romano, \\ Antonella Sciarra, ${ }^{4}$ Alessandra Sacco $\left(\mathbb{D},{ }^{5}\right.$ Giuliana Settembre $\mathbb{D}^{2},{ }^{2}$ Mario Coppola, ${ }^{2}$ \\ Angelina Di Carlo, ${ }^{6}$ Luigi D'Angelo, ${ }^{1}$ Francesco Inchingolo, ${ }^{7}$ Antonia Feola ${ }^{(D},{ }^{3}$ \\ and Marina Di Domenico $\mathbb{D}^{2,8}$
}

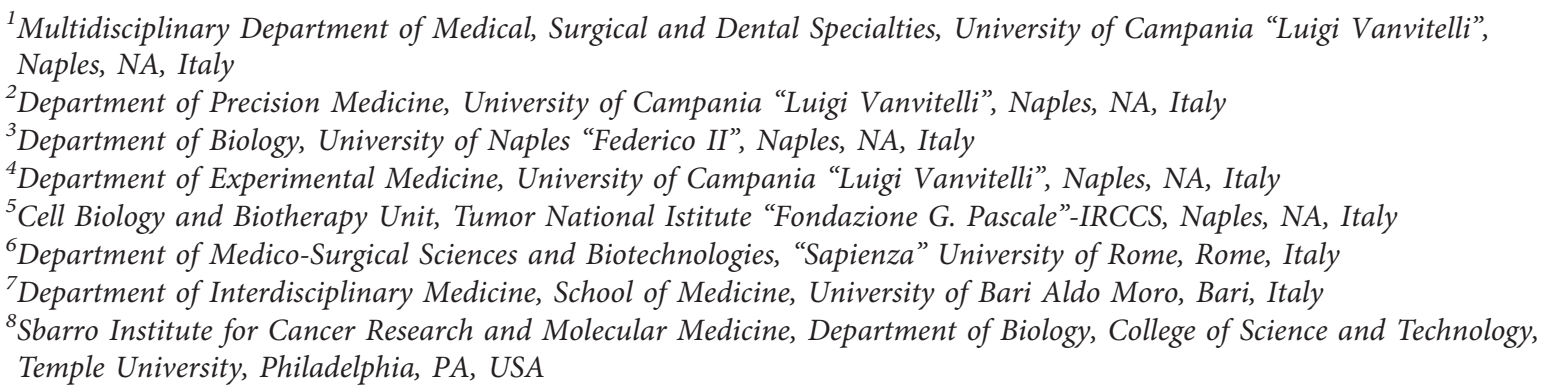

Correspondence should be addressed to Antonia Feola; antonia.feola@unina.it

Received 29 January 2020; Revised 3 June 2020; Accepted 6 June 2020; Published 27 June 2020

Academic Editor: Francesca De Felice

Copyright (c) 2020 Maria Contaldo et al. This is an open access article distributed under the Creative Commons Attribution License, which permits unrestricted use, distribution, and reproduction in any medium, provided the original work is properly cited.

Oral cancers have been proven to arise from precursors lesions and to be related to risk behaviour such as alcohol consumption and smoke. However, the present paper focuses on the role of chronic inflammation, related to chronical oral infections and/or altered immune responses occurring during dysimmune and autoimmune diseases, in the oral cancerogenesis. Particularly, oral candidiasis and periodontal diseases introduce a vicious circle of nonhealing and perpetuation of the inflammatory processes, thus leading toward cancer occurrence via local and systemic inflammatory modulators and via genetic and epigenetic factors.

\section{Introduction}

Oral squamous cell carcinoma (OSCC) is the most frequent malignancy of the oral cavity, accounting for more than $90 \%$ of malignant tumors of this anatomic site $[1,2]$ and often arise from precursor lesions [3-5].

OSCC overall survival has been proven to be strictly related to the time of diagnosis and, in addition to the classical prognostic indicators [6-8], biological markers [9-13] and the recognized risk factors, such as alcohol and smoke [14], a key role in carcinogenesis has been recently assigned to chronic inflammation and/or infections, which may lead toward genetic and epigenetic changes involved in the malignant transformation of the oral keratinocytes [15-18].

\section{Action of Acute and Chronic Inflammations in Oral Disorders}

Inflammation is an early protective and localized response of the tissue to infections, radiations (UV), injuries, and chemicals. The inflammatory pathway localizes and disrupts the pathogen, repairs the damaged tissue, and regulates the altered homeostasis. Depending on the duration, inflammation is acute, when it resolves in a few days or chronic, which does not resolve because of the persistence of 
pathogen or tissue injury and may lead to pathologies such as cancer $[19,20]$.

\subsection{Action of Phlogistic Mediators in Cancer Development.} The inflammation pathway is activated by innate immune cells that, thanks to their membrane receptors, identify and recognize pathogens and activate different response pathways through the production of phlogistic mediators [21]. Among the cells involved in the inflammation process, an important role is played by macrophages, involved during all phases of inflammation. In the first step of the inflammation, macrophages bound the tissue site and differentiate from circulating monocytes, acquiring distinct characteristics and functions in response to the specific pathogens. Thanks to their receptor, they recognize pathogens and lead to cytokines production by epithelial cells involving the activation of toll-like receptor (TLR) signaling. The cytokines and chemokines generated at the damage site activate and recruit neutrophils that have a pivotal role in the cascade, by trapping and killing the pathogens [22, 23]. Neutrophils are able to engulf, reduce to granules, and release the nuclear chromatin as neutrophil extracellular traps (NETs) (neutrophil extracellular traps in immunity and disease) [24], and to produce several cytokines and other phlogistic mediators that influence and regulate inflammation and immunity $[25,26]$. When the immune system fails to vanquish the pathogen source of acute inflammation, chronic inflammation response is established. This pathological status is a further attempt of the body to free itself from the pathogenic insult, it influences several metabolic processes including cell homeostasis, inducing genomic changes, which in the long run can promote carcinogenesis [27].

Moreover, several studies have suggested a pivotal role of chronic inflammation in carcinogenesis and have considered it as a risk factor for most types of cancer [28-33]. According to Mantovani et al., inflammation and cancer share two pathways. The extrinsic pathway is related to those chronic inflammatory conditions that increase cancer risk; the intrinsic pathway is related to genetic alterations responsible for inflammation and tumor, such as oncogenes activation and oncosuppressor inactivation (Figure 1) [34].

Many proinflammatory mediators play a critical role in the suppression of apoptosis, proliferation, angiogenesis, invasion, and metastasis, including TNF superfamily, interleukins, chemokines, MMP-9, VEGF, COX-2 and 5-LOX [35-37].

The expression of all these proteins is mainly regulated by $\mathrm{NF}-\kappa \mathrm{B}$, a transcriptional factor that is constitutively active in most tumors and is induced by carcinogens (such as cigarette smoke), tumor promoters, and carcinogenic viral proteins. It can mediate tumorigenesis directly, acting as a growth factor for tumor cells, and indirectly through the action of its gene products $[38,39]$.

TNF- $\alpha$ is one of the major mediators of inflammation, is mainly produced by macrophages, and is induced by a wide range of pathogenic stimuli. Once secreted, TNF- $\alpha$ can mediate a variety of diseases, including cancer [40]: it can induce cellular transformation, proliferation, and tumor promotion [41]. TNF- $\alpha$ activates IKK, that, in turn, phosphorylates $\mathrm{IKB}$, causing its rapid polyubiquitination $[42,43]$. In this way, $\mathrm{NF}-\kappa \mathrm{B}$ is no longer retained in the cytoplasm, can translocate to the nucleus, and promotes target genes transcription, including cIAP-1, cIAP-2, Bcl$\mathrm{xL}$, XIAP, and IEX-1L, all with antiapoptotic proprieties [44]. Moreover, NF- $\kappa$ B suppresses the apoptotic JNK activation and mediates expression of antiapoptotic and antioxidant genes, blocking cell death and facilitating cancer cell proliferation [45]. Therefore, the balance of TNF-induced survival and death signaling is pivotal in determining the fate of cellular response induced by TNF. Modulating this balance could help to prevent cancer development [46].

Even several inflammatory interleukins are involved in tumorigeneses, such as IL-1, IL-6, IL-8, and IL-18, suggesting that inflammation is associated with cancer development. In particular, the secretion of IL-1a promotes growth in cervical carcinoma [47], while autocrine production of IL-1b promotes growth and confers chemoresistance in pancreatic carcinoma cell lines [48]. IL-6 acts as a paracrine growth factor for multiple myeloma, nonHodgkin's lymphoma, bladder cancer, colorectal cancer, and renal cell carcinoma (RCC) [49-53]. Another important proinflammatory cytokine is IL-8, which promotes the growth and metastasis of many tumors, like astrocytomas, anaplastic astrocytomas, glioblastomas, and central nervous system cervical carcinoma metastasis [54-56].

Chemokines can be involved in cancer progression too, including angiogenesis, inflammation, cell recruitment, and migration. Therefore, they promote tumor development, inducing angiogenesis and tumor growth, directly or indirectly through the recruitment of tumor-associated macrophages [57].

2.2. Inflammatory Condition Involved in Oral Cancer. In the pathogenesis of oral squamous cell carcinoma are involved many oral inflammatory conditions: oral submucous fibrosis, oral lichen planus, discoid lupus erythematosus, oral ulcers related to repetitive tissue injury, and chronic periodontal disease [58].

Oral submucous fibrosis is a potentially malignant condition, characterized by dense fibrosis of the lamina propria at the affected site, by a juxtaepithelial inflammatory reaction and by atrophy or hyperplasia of the overlying epithelium. The inflammatory infiltrate comprises mainly lymphocytes, but also plasma cells and macrophages [59-62].

The process of fibrosis is characterized by the production of inflammatory mediators and growth factors, including prostaglandins, reactive oxygen species, TNF- $\alpha$, IL-8, IL-6, TGF- $\beta$, platelet-derived growth factor, and basic fibroblast growth factor, by oral keratinocytes and inflammatory cells within the lamina propria $[63,64]$. In the inflamed microenvironment of the submucous fibrosis TNF- $\alpha$, IL- 6 and PGE-2 may favour malignant transformation of the 


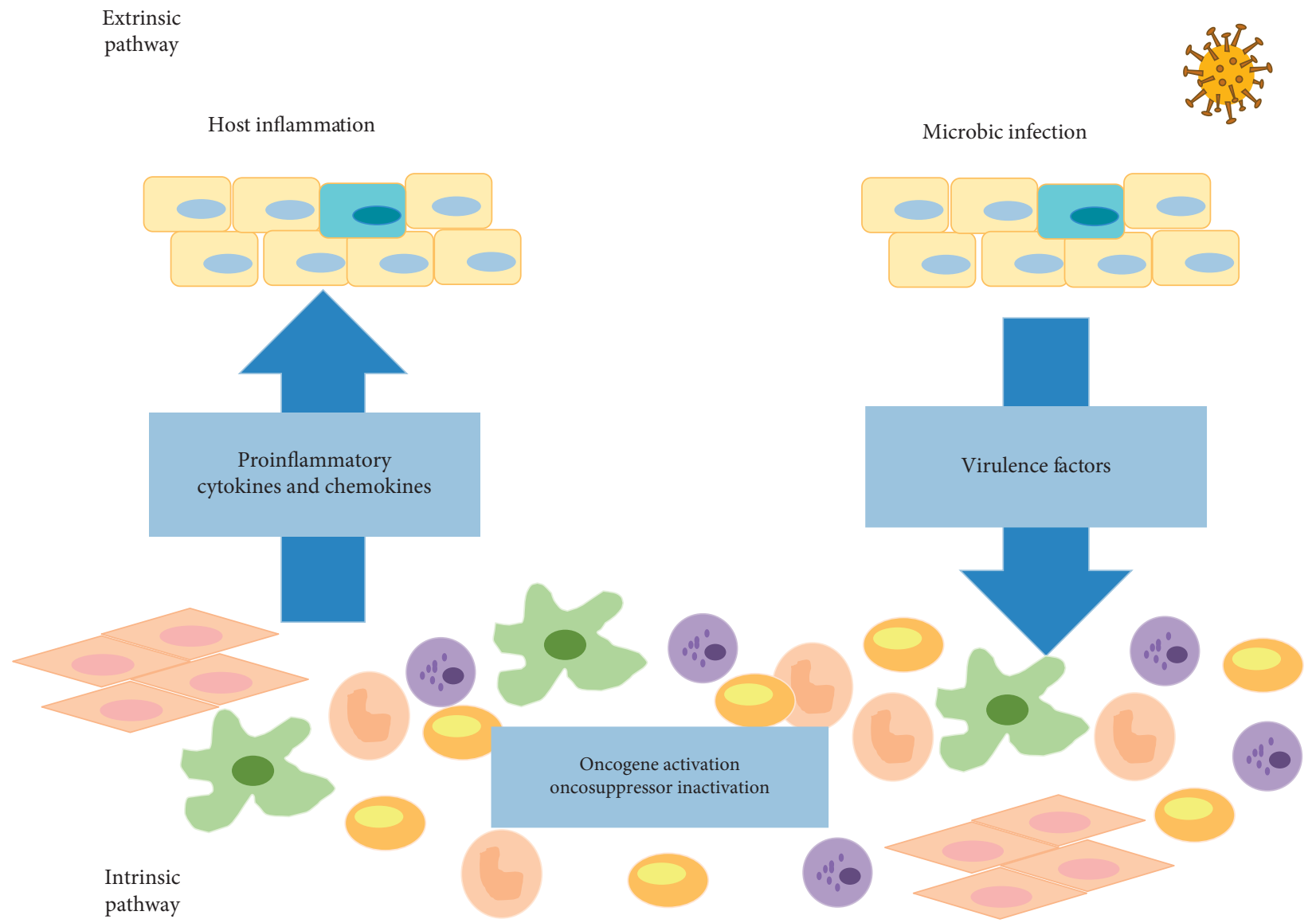

FIGURE 1: Cancerogenetic changes and inflammatory triggers are both involved in oral cancer onset by a two-way interrelated pathway, involving intrinsic and extrinsic events toward cancerogenesis. The intrinsic factors include genetic and epigenetic phenomena bringing the keratinocyte toward malignant transformation (oncogenes activation/oncosuppressor inactivation) and the production of inflammatory cancer-related mediators that recruit inflammatory cells. The extrinsic pathway is related to an underlying inflammatory/infectious state, which can promote cancerogenesis via the production of inflammatory cytokines that activate a series of transcription factors responsible for tumorigenesis. Both pathways bring toward the production of further phlogistic mediators and cancer-promoting transcription factors, thus creating a microenvironment where inflammation and cancer feed on each other.

precancerous keratinocytes and their clonal expansion. After the acquisition of additional genetic alterations, some of these proliferating precancerous keratinocytes may obtain a malignant phenotype [65].

In addition, oral lichen planus can represent a risk for oral squamous cell carcinoma $[66,67]$ : it is characterized by a $\mathrm{T}$ cell-mediated chronic immunoinflammatory reaction against a yet undefined antigen within the basal cell layer of the oral epithelium [68]. When it happens, oral lichen planus evolves to OSCC, and the local inflammatory microenvironment provides the activation of transcriptional factors that promote the proliferation of the epithelial cells affected by the lichen planus, but also angiogenesis, invasion, and metastasis $[69,70]$.

Moreover, the bacteria of dental-gingival plaques and their products, through local inflammatory responses, the production of nitrosamines, and mutagenic agents formed, have the capacity to start mitogenic and antiapoptotic pathways in oral keratinocytes. Thus, oral bacteria and inflammatory mediators associated with periodontal disease may be cofactors in the promotion of oral squamous cell carcinoma $[71,72]$.

Therefore, there are several pieces of evidence that demonstrate the link between chronic inflammation and cancer, and inflammatory biomarkers described can be used to monitor the progression of the disease.

\section{Role of Sex Hormones in Cancer}

Hormones are naturally produced in our body and they are fundamental to guide its functions [73]. Their production is finely regulated by the human organism because even a small alteration in their quantities can be the cause of serious repercussions on the whole organism [74]. Among the many functions performed by hormones, some concern also cells proliferation and can influence the risk of cancer [75-78]. As an example, excessive levels of sex hormones (like estrogens and androgens) can promote the development of breast and prostate cancer in women and men, respectively $[79,80]$. 
The association of the estradiol receptor (ER) with Src triggered by steroid agonists growth factors controls breast and prostate cancer cell growth. To understand this mechanism, Varricchio et al. have shown that this association is abolished in whole cells and in vitro by a sixamino-acid peptide that mimics the sequence around the phosphotyrosine residue in position 537 of the human ER-alpha, indicating that the peptide specifically targets the ER-associated Src [81].

The main mechanisms by which hormones influence cancer development are by controlling the rate of cell division, the differentiation of cells, and the number of susceptible cells [82]. Sex hormones, for example, have very marked effects on cell division in the endometrium; particularly, estrogens stimulate mitosis, while progestins oppose this effect $[83,84]$. Nowadays, it is clear the mechanisms through which estrogens cause cancer [85]. It is well known that estrogen receptor ER $\alpha$ is certainly involved in cell cycle process, cell migration, and invasion (as demonstrated on MCF-7 cellular model [86]) and that there is a strong association of estrogen dose and length of exposure with increased breast cancer risk [87]. In many steroid-dependent cancers, there is an interaction between growth factor and steroid signaling, which converge in the PI3K/AKT pathway $[88,89]$. There are many experimental pieces of evidence showing that the phosphorylation of $\mathrm{p} 85 \alpha \mathrm{SH} 3$ domain, the regulatory subunit of PI3K, represents a crucial step for the activation of this pathway [90]. PI3K/AKT pathway controls cell cycle progression, cell growth, proliferation, apoptosis, adhesion, and migration through various downstream effectors and, in the end, could be involved in the growth of cancers [91]. PI3K/AKT is the most frequently mutated pathways in cancer, and most of the $\mathrm{p} 85 \alpha^{\mathrm{PI} 3 \mathrm{~K}}$ mutations cluster in the inter-SH2 (iSH2) domain of the molecule, which interacts with the catalytic subunit $\mathrm{p} 110 \alpha^{\mathrm{PI} 3 \mathrm{~K}}$ [92]. It is known that PKA phosphorylation of serine at codon 83 (S83), adjacent to N-terminus SH3 domain in the PI3K regulatory subunit $\mathrm{p} 85 \alpha$, is involved in cell cycle progression and cell survival in normal epithelium, influencing the ability of $\mathrm{SH} 3$ domain to interact with different partners [93, 94]. Among these, PI3K activates AKT, localizing it in the plasma membrane [95]; in turn, AKT, once activated, can have several downstream effects such as activating CREB [96], inhibiting p27, and activating mTOR [97]. The result of AKT activation is represented by the induction of cell growth and resistance to apoptosis, both processes involved in many cancers [98]. Nearly all receptors binding p85 $\alpha^{\mathrm{PI} 3 \mathrm{~K}}$ can cooperate with cAMP-PKA signals via phosphorylation of $\mathrm{p} 85 \alpha^{\mathrm{PI} 3 \mathrm{~K}} \operatorname{Ser} 83[88,99]$ : $\mathrm{ER} \alpha$ and retinoic acid receptor-alpha $(\operatorname{RAR} \alpha)$ have been extensively studied for their association with PI3K and their involvement in cancer risk $[100,101]$. The PI3K/AKT/ mTOR pathway is altered in around $30.5 \%$ of HNSCC patients $[102,103]$. The AKT/mTOR pathway plays an essential role in regulating the formation of blood vessels in both normal and cancer tissues. Angiogenesis is characterized by the secretion of vascular endothelial growth factor (VEGF), basic fibroblast growth factor (bFGF), and interleukins such as IL-8 by cancer cells [104].

3.1. Sex Hormones in Oral Cancer Development and Progression. The role of sex hormones is well known in cases of prostate, breast, and endometrial carcinomas; instead, the involvement of sex hormones in HNC (head and neck cancer) is still controversial. Probably sex hormones affect cancer risk by increasing the number and mitotic rate of the epithelial cells in the organ concerned [105]. In fact, high mitotic rates can increase cancer risk because there are more chances of mutations that can be replicated before being repaired and can also increase the growth of early tumors. Moreover, in the case of estrogens, some metabolites of estradiol may cause mutations by directly damaging the DNA, but the importance of this possible process has not been established yet [106]. HNC includes all malignant tumors that derive from the moist squamous cell mucosa or lining of the head and neck regions and comprises malignancies of the nasal cavity and paranasal sinuses, oral cavity, pharynx, larynx, and salivary glands [107]. Recent literature suggests that, apart from the major established risk factors (alcohol and smoking), female sex hormones may contribute to head and neck carcinogenesis, and it indicates certain endocrine involvement in its development [108].

The expression of sexual hormone receptors in some tumors underlines a role for these molecules in cancer pathogenesis. Colella et al. investigated the presence and expression levels of sexual steroid receptors in OSCC. They found that ER $\alpha$ mRNA is more expressed in the OSCC than in control tissues, while opposite results have been obtained for AR [107].

It is known that AR binds to specific DNA sequences and affects the transcription of various genes. Fan and Malhelm suggested that AR may have a role in the pathogenesis of salivary duct carcinoma through the production of an epidermal growth factor receptor and making growth factor- $\alpha$ autocrine pathway similar to what happens in prostatic carcinoma [109]. In addition, some studies have shown that androgens affect the expression of proto-oncogenes (like c-myc) and apoptotic factors (like the bcl-2 family) in lacrimal, salivary, and prostatic tissues of both mice and rats, as well as in cell line models [110]. Therefore, the expression of sex hormone receptors in some tumors certainly suggests a role for these receptors in cancer pathogenesis, progression, and therapy.

Some studies have demonstrated that elevated prolactin levels in HNC can be a marker of poor prognosis [111]. Few other studies have shown increased levels of FSH, LH, and prolactin and decreased ratio of testosterone/estradiol in tongue cancer patients. This indicates a disruption of the pituitary-adrenal-testicular axis and suggests that these hormones might play a crucial role in the development and progression of oral cancer [112].

In addition, some recent reports have shown pieces of evidence that salivary gland tumors are similar to breast 
cancer from a molecular and cellular point of view [113]. Both tumors show a similar expression of progesterone associated with cancer progression [114]. Moreover, estrogens may induce the movement of precancerous cells in the mouth and promote the spread of head and neck cancers [115].

\section{Functions of Infection and Epigenetic Modification in Oral Carcinogenesis}

Hence, chronic infections and/or dysimmune diseases may sustain a chronic inflammatory state, which represents a risk factor for carcinogenesis. Indeed, immunity and inflammation usually fight against the pathogens to reduce the risk of dissemination and to support repairing mechanisms. However, in some cases, these systems are unable to totally eradicate the infection and/or its recurrence, thus supporting genetic and epigenetic changes toward carcinogenesis in the cells of the involved tissues. Furthermore, in the tissues where the inflammatory/ immune responses take place [116], the onset of oxidative stress, associated with the chronic inflammatory state, takes part in the pathogenic mechanisms [117-119] responsible for carcinogenesis of such oral diseases [120-122]. Different chronic inflammatory and dysimmune conditions may affect the oral structures $[123,124]$, thus giving rise to an endless circle of inflammatory events leading toward chronicity and increase of the risk of cancer transformation and metastasis [125]. This condition is a significant attributable factor for poor prognosis and circulating tumor cells CTCs are shedding by a primary clone and are responsible for oral cancerrelated deaths [126]. Various pilot studies show that serum miRNA signature might be a potential biomarker for early detection of cancer and, in particular, a threeplasma miRNA panel (miR-222-3p, miR-150-5p, and miR-423-5p) may be useful to monitor malignant progression from OSCC $[127,128]$. miRNAs are considered biomarkers for gene expression. They influence the regulation of cellular processes such as cell differentiation, proliferation, and apoptosis. The aberrations in miRNA expression predict that miRNA identification in oncogenesis might reveal networks or targets that are suitable for cancer diagnostic markers or cancer therapy [129-131].

4.1. Oral Infections Involvement in Inflammation Process. Not only the chronic inflammation infection-related is responsible for cancerogenesis, but also bacteria, fungi, and viruses themselves are strongly implicated as etiological factors in cancers [132]. The most investigated associations are between HPV and oropharyngeal carcinomas and Candida spp overinfected oral lichen planus and OSCC [133-135].

Oral microbiota homeostasis is fundamental to maintain the state of oral health. Each dysbiosis or unbalanced spread of pathogens give rise to several infectious diseases of both teeth and mucosae, which can perseverate in a chronic condition [136], during which the reparative processes fail, due to the inflammatory effects themselves. As reported by Zhang et al., OSCC tissues show a higher number of bacteria and significant changes in microbiota compared to the normal tissues in the buccal mucosa [137]. Furthermore, oral microbiota unbalance can influence not only oral cancer onset, but it can also lead to systemic diseases and chronic inflammation, such as cardiovascular diseases, diabetes, rheumatoid arthritis, neurodegenerative diseases, and skin psoriasis [138]. The most investigated oral disease where infection, oral dysbiosis, chronic inflammation, and systemic involvements have been variously proven is periodontitis, a chronic inflammatory disorder responsible for the loss of dental elements. Periodontal chronic inflammation is triggered by specific bacterial species colonizing the gingival pockets of predisposed subjects and sustained by genetic $[139,140]$ and environmental factors [141]. Eke et al., in 2012, evaluated the prevalence of the periodontal disease in the United States, providing evidence for the priority function of transforming growth factor- $\beta$ platelet-derived growth factor, IL-1 and keratinocyte growth factor, which may be related the crosstalk between fibroblasts and keratinocytes, affecting wound and periodontal healing process [142]. If the association among periodontitis and endocarditis has been proven by several studies [143], the interrelationship among periodontitis associated bacteria and cytokine expressions, and their responsibilities toward the onset of bone and inflammatory systemic diseases, such as osteoporosis and rheumatoid arthritis, have also been elucidated by Ballini et al. in 2015 [144], which reported that bacterial-associated molecules, such Porphyromonas gingivalis' ones, may interact with their surface receptors in the immune cells, thus inducing the production of several cytokines and chemokines with a proinflammatory role and allowing the activation of mechanisms related to osteoporosis and rheumatoid arthritis. Among common infections affecting the oral cavity, Candidiasis often arises in subjects suffering systemic diseases [145] and/or local factor [146], or salivary alterations [147] which dysregulate the oral microbiome, leading to the spread of a series of microbial and fungal infections [148-150], which may persist in a chronic or recurrent state [151], and that can be associated with the oral mucosae cancerization. The expression and phosphorylation state of EGFR and the expression of cadherins could be considered to monitor oral cancer progression.

4.2. Relationship between Genetic and Epigenetic Changes in Cancer. Genetic research has underlined several interactions between environmental and epigenetic factors, aiming to highlight the molecular genetic markers with clinical signs and risk factors for periodontitis [152]. A more modern scientific approach to understand periodontitis vulnerability is involved in recognizing the susceptibility to inflammatory process for DNA mutations of specific cytokine genes. While the prognostic 
significance of the quantitative and topographic dysregulation of proteins of the cadherin families and the methylation of their genes or downregulation of their mRNA have been widely proven to be related to cancer progression [153-157], authors such as Loo et al. hypothesize their responsibilities toward chronic periodontitis too [158]. Many investigators have evaluated the association between genetic polymorphisms in humans with different periodontal disease patterns; these studies pointed out that genetic polymorphisms in some candidate genes are involved in interindividual variations in their response to periodontitis [159]. Genetic bases, in fact, are involved in the proinflammatory signaling pathways, through proteins expression and regulation [160]: changes in gene expression seem to generate inflammatory cytokines activation, responsible for periodontitis pathogenetic cascade, as recently assessed by Rudick et al. [161]. The genetic model predisposition for early-onset periodontitis was hypothesizes in 1994 by Marazita et al.: they focused on individual's immune response as the key role to interpret the susceptibility to progression of periodontal disease. Polymorphonuclear leukocytes decrease, in fact, is noted to strongly affect vulnerability to periodontitis. To date, moreover, it seems to be established that cytokines overexpression, influenced by the immune cells ongoing, leads to empowerment of the pathogenetic pathway. Several kinds of cytokines seem to be involved: SNPs of IL$1 \alpha$, IL- $1 \beta$, IL-4, IL-6, IL-8, and IL-18 located in different regions of the cytokine genes have been shown to affect the risk of the disease in several populations [162]. The most suggestive aspect is related to IL-1 polymorphisms, which has shown as a promoter in the enhancement of periodontal disease. Indeed, in 1995 Hassel and Harris have paid great attention to "Periodontitis associated genotype (PAG)," as a significant increasing marker in patients with advanced periodontitis and dental caries [163]. Epigenetic linkage with periodontal disease seems to recognize not only IL-1 polymorphisms relationship, but also a moderate association with hypermethylation of E-Cadherin and cyclooxygenase 2 [164, 165]. Recently, Cantore et al. confirmed these data by molecular analyses reporting a statistically significant correlation between the severe form of periodontitis and the presence of IL- $1 \alpha(+4845)$ and IL$1 \beta(+3954)$ single nucleotide polymorphisms (SNPs) [166], refuting previous studies that identified a marked contribution of IL-1 in development of periodontitis and that refused it as essential on disease risk [167]. In addition, Gomez et al. in 2009 found hypomethylation of IL- 6 gene in people with periodontal disease [168] and Küchler et al., recently, have deeply reviewed the literature to investigate how apical periodontitis pathogenesis ranges from microbial to genetic factors [137]: the most suggestive results emphasized the interindividual variation in apical periodontitis pathogenesis and severity of host response (phenotype). Although literature showed a lack of studies in the field of epigenetic factors related to periodontitis, a strong association has been found between IL-1B and TNF- $\alpha$ polymorphism and persistent apical periodontitis [169]. Further studies aiming to rate the genetic risk for periodontitis have focused on molecular levels of IL-1, IL6 , TNF- $\alpha$, Vitamin-D receptor, Fc-gamma receptor, IL-10, and matrix metalloproteinase $[170,171]$. The interest in the determination of the diagnostic value of metalloproteinases, in fact, is well known not only in periodontal diseases [172] but also in caries, pulp, and periapical inflammations $[173,174]$ and some cancers [175-177]. Moreover, other authors focused on genetic disorders related to periodontitis, since several syndromes, such as Chèdiak-Higashi, trisomy 21, Ehlers-Danlos, Papillon-Lefèvre, Haim-Munk, leukocyte adhesion deficiency (LAD), and lazy leukocyte syndrome, show a periodontal disease history, due to anomaly in aggregation and action of neutrophils [178]. Although there is still no evidence about an interlink between syndromic genetic mutations and periodontitis and no genetic tests are currently utilized, the Research Science and Therapy Committee of American Academy of Periodontology in 2005 has compiled an informational paper showing promising results of tests for genetic IL-1 polymorphisms as a genomic risk factor for periodontitis [179]. Recently, it is demonstrated that laser irradiation enhanced mitogen activity compared to nonlasered control cells on the growth rate and differentiation of human osteoblast-like cells seeded on titanium or zirconia surfaces [180]. Furthermore, a recent systematic review elucidated a statistically significant difference in the levels of some salivary cytokines (IL-6, CCL3, TGF- $\beta$, CXCL8, GM-CSF, and TNF- $\alpha$ ) between subjects with denture stomatitis and controls $(P<0.05)$ and, on the other side, the lack of significant differences in the same group/control pair, as regards IL-2, IL-12, IFN- $\gamma$, IL-4, IL-8, IL-10, IL-17, TNF$\alpha$, and ICAM-1 [181]. Significant differences in levels of some cytokines have also been identified in dental inflamed pulp [182], where a significant increase in levels of IL- $1 \beta$, IL-2, IL-6, IL- 8 , and TNF- $\alpha$ was typically found in irreversible pulpitis samples, in comparison to normal pulp samples (Figure 2). Last but not least, the role of some kinds of viral infections [183] is the most reported condition of carcinogenesis of the head and neck mucosae [184-186], particularly with regard to oropharyngeal cancers [18] but also to OSCCs, where Pannone et al. identified among a series of OSCCs, a subgroup characterized by HPV infection (10.5\%), in which the oncogenic role of HPV70 was confirmed, via p53 protein inactivation, and the consequent cell immortalization promotion and the oncogenic risk of HPV-53 which produced HPVE7 protein and inactivated $\mathrm{pRb}$ oncosuppressor pathway [187-190]. 


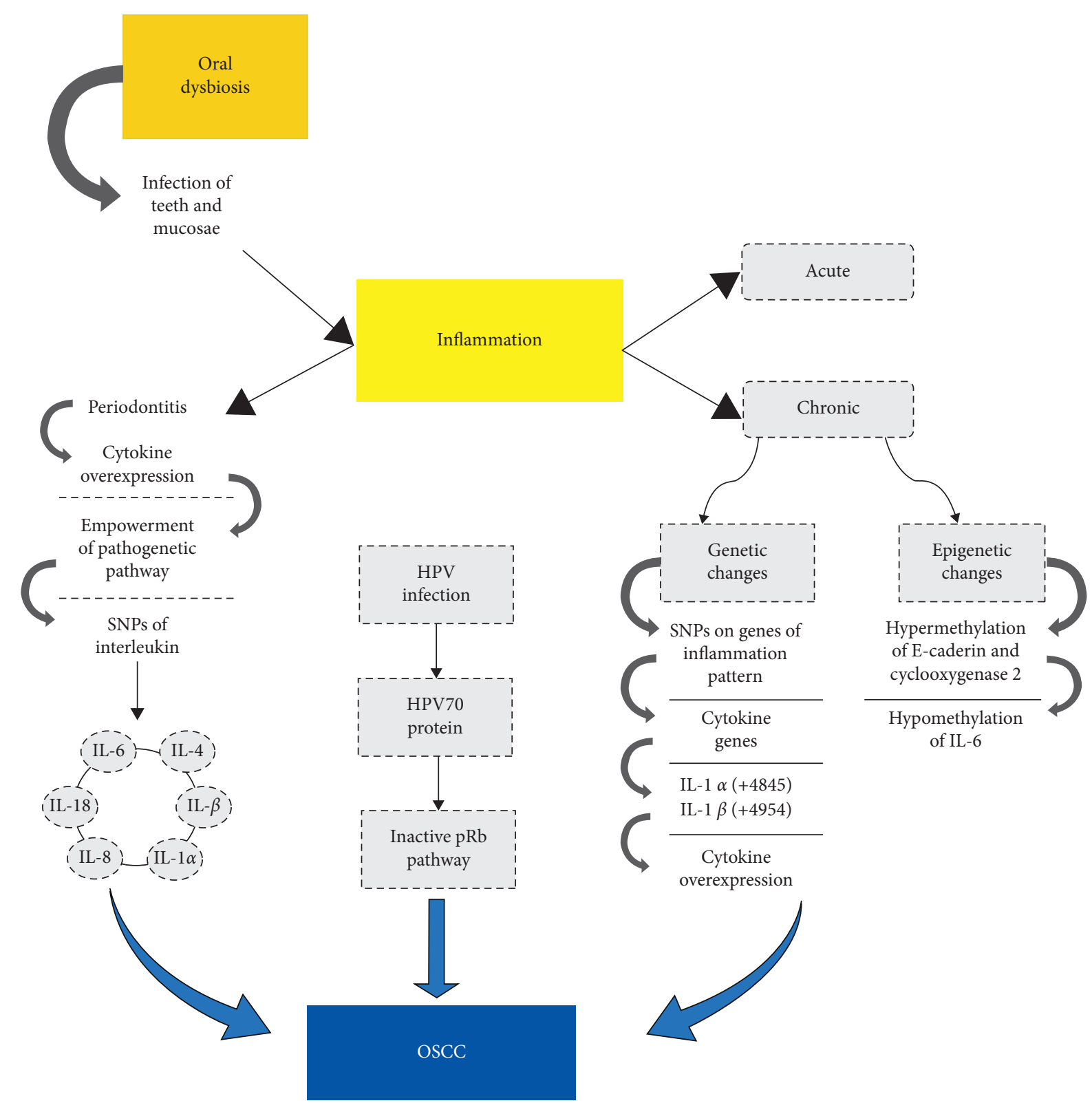

FIGURE 2: Schematic representation of the relation between oral squamous cell carcinoma (OSCC), inflammation, and periodontitis. The figure represents the different mechanisms involved in the development of the OSCC in relation to inflammation. The chronic one is correlated to periodontitis disease and may lead to genetic and epigenetic changes like cytokine, SNPs. This mutation involved mainly IL- $\alpha$ and IL- $\beta$ which are overexpressed.

\section{Conclusions}

The present work aimed to highlight the roles of sex hormones, oral chronic infections, and auto/dysimmune diseases in the onset of oral cancerization. The responsibilities of estrogens and androgens have been clearly proven about breast and prostate cancers, while estrogen receptor-alpha $(\operatorname{ER} \alpha)$ and retinoic acid receptor-alpha $(\operatorname{RAR} \alpha)$ have been extensively studied for their involvement in cancer risk, also with regard to oral cancers. Many pieces of evidence reported in this review may help to understand the risk factors that cause HNC in addition to the traditional risk factors, that is, tobacco and alcohol exposure. Here, we discuss that sex hormones may influence the normal-dysplasia-cancer evolution of the oral mucosa, and this could contribute to understand the molecular pathways of chemotherapy for OSCC. In fact, we think that it could be useful to consider specific antagonists against sex hormone receptors. Even treatments such as vitamin A and beta carotene have been reported to be effective in healing oral leukoplakia [191] and RAR $\beta$ expression inhibits oral squamous cell carcinoma bone invasion [192]. Furthermore, chronic inflammation occurring during oral infections and/or dysimmune diseases represents a risk factor for carcinogenesis, as well reported with regard to the oncogenic potential of such oral infections sustained by Candida spp. Lastly, in addition to the 
consolidate association among periodontitis and heart diseases such as endocarditis [193], an increasing number of researches point on the role of Porphyromonas gingivalis, usually reported as involved in the onset of periodontitis, as associated with oral and extraoral carcinogenesis [194]. The present report suggests that the described signaling proteomic and cellular effectors may have therapeutic applications for oral squamous patients [195-198]. In conclusion, inflammatory and infectious processes sustaining periodontitis and other oral affections are associated with the onset of oral cancer, sustained by local and systemic inflammatory cascades and by genetic and epigenetic factors.

\section{Abbreviations}

\begin{tabular}{|c|c|}
\hline 5-LOX: & 5-lipoxygenase \\
\hline AR: & Androgen receptor \\
\hline b-FGF: & Basic fibroblast growth factor \\
\hline Bcl-xL: & B-cell lymphoma-extra large \\
\hline cAMP: & Cyclic adenosine monophosphate \\
\hline CCL3: & Chemokine (C-C motif) ligand 3 \\
\hline cIAP-1, -2: & Cellular inhibitor of apoptosis protein-1, -2 \\
\hline COX-2: & Cyclooxygenase 2 \\
\hline CREB: & cAMP response element-binding protein \\
\hline CXCL8: & Interleukin 8 \\
\hline $\mathrm{ER} \alpha:$ & Estrogen receptor-alpha \\
\hline FSH: & Follicle-stimulating hormone \\
\hline GM-CSF: & $\begin{array}{l}\text { Granulocyte-macrophage colony-stimulating } \\
\text { factor }\end{array}$ \\
\hline HNC: & Head and neck cancer \\
\hline HNSCC: & Head and neck squamous cell carcinoma \\
\hline HPV: & Human papilloma virus \\
\hline ICAM-1: & Intercellular adhesion molecule 1 \\
\hline IEX-1L: & Radiation-inducible immediate-early gene \\
\hline IFN- $\gamma:$ & Interferon gamma \\
\hline IKK: & $\mathrm{I} \kappa \mathrm{B}$ kinase \\
\hline IL-: & Interleukin \\
\hline LAD: & Leukocyte adhesion deficiency \\
\hline LH: & Luteinizing hormone \\
\hline miR: & microRNA \\
\hline MMP-9: & Matrix metallopeptidase 9 \\
\hline mTOR: & Mammalian target of rapamycin \\
\hline NETs: & Neutrophil extracellular traps \\
\hline $\mathrm{NF}-\kappa \mathrm{B}:$ & $\begin{array}{l}\text { Nuclear factor kappa-light-chain-enhancer of } \\
\text { activated B cells }\end{array}$ \\
\hline OSCC: & Oral squamous cell carcinoma \\
\hline $\mathrm{p} 110 \alpha^{\mathrm{PI} 3 \mathrm{~K}}:$ & $\begin{array}{l}\text { Phosphoinositide-3-kinase p110 alpha catalytic } \\
\text { subunit }\end{array}$ \\
\hline $\mathrm{p} 85 \alpha^{\mathrm{PI} 3 \mathrm{~K}}:$ & $\begin{array}{l}\text { Phosphoinositide-3-kinase p } 85 \text { alpha regulatory } \\
\text { subunit }\end{array}$ \\
\hline PAG: & Periodontitis associated genotype \\
\hline PGE-2: & Prostaglandin E2 \\
\hline PI3K/AKT: & Phosphoinositide-3-kinase/Protein kinase B \\
\hline PKA: & Protein kinase A \\
\hline $\operatorname{RAR} \alpha:$ & Retinoic acid receptor-alpha \\
\hline SH2 and 3: & Src H2 homology domain \\
\hline SNPs: & Single nucleotide polymorphisms \\
\hline Src: & Proto-oncogene tyrosine-protein kinase \\
\hline TGF- $\beta$ : & Transforming growth factor beta \\
\hline
\end{tabular}

TLR: Toll-like receptor

TNF- $\alpha$ : Tumor necrosis factor alpha

VEGF: Vascular endothelial growth factor

XIAP: X-linked inhibitor of apoptosis protein.

\section{Conflicts of Interest}

The authors declare that they have no conflicts of interest.

\section{Authors' Contributions}

Maria Contaldo and Mariarosaria Boccellino contributed equally to this study.

\section{References}

[1] D. Lauritano, A. Lucchese, M. Contaldo et al., "Oral squamous cell carcinoma: diagnostic markers and prognostic indicators," Journal of Biological Regulator and Homeostatic Agents, vol. 30, no. 2, pp. 169-176, 2016.

[2] G. Favia, L. Lo Muzio, R. Serpico, and E. Maiorano, "Angiosarcoma of the head and neck with intra-oral presentation. A clinico-pathological study of four cases," Oral Oncology, vol. 38, no. 8, pp. 757-762, 2002.

[3] A. Santoro, L. Laino, M. Contaldo et al., "Adenocarcinoma NOS of the maxillary sinus: clinical and histopathological features with therapeutic considerations," Otolaryngology, vol. 1, no. 1, pp. 2-4, 2011.

[4] F. Ricciardiello, M. Caraglia, B. Iorio et al., "Aggressiveness pattern and second primary tumor risk associated with basaloid squamous cell carcinoma of the larynx," Oncotarget, vol. 8, no. 56, pp. 95791-95798, 2017.

[5] A. Santoro, G. Pannone, M. Contaldo et al., "A troubling diagnosis of verrucous squamous cell carcinoma ("the bad kind" of keratosis) and the need of clinical and pathological correlations: a review of the literature with a case report," Journal of Skin Cancer, vol. 2011, Article ID 370605, 4 pages, 2011.

[6] M. Contaldo, A. Di Napoli, G. Pannone et al., "Prognostic implications of node metastatic features in OSCC: a retrospective study on 121 neck dissections," Oncology Reports, vol. 30, no. 6, pp. 697-704, 2013.

[7] G. Aquino, G. Pannone, A. Santoro et al., "pEGFR-Tyr 845 expression as prognostic factors in oral squamous cell carcinoma," Cancer Biology \& Therapy, vol. 13, no. 11, pp. 967-977, 2012.

[8] M. Contaldo, A. Lucchese, E. Gentile et al., "Evaluation of the intraepithelial papillary capillary loops in benign and malignant oral lesions by in vivo virtual chromoendoscopic magnification: a preliminary study," Journal of Biological Regulators and Homeostatic Agents, vol. 31, pp. 11-22, 2017.

[9] S. De Maria, G. Pannone, P. Bufo et al., "Survivin geneexpression and splicing isoforms in oral squamous cell carcinoma," Journal of Cancer Research and Clinical Oncology, vol. 135, no. 1, pp. 107-116, 2009.

[10] G. Pannone, S. A. H. Hindi, A. Santoro et al., "Aurora B expression as a prognostic indicator and possibile therapeutic target in oral squamous cell carcinoma," International Journal of Immunopathology and Pharmacology, vol. 24, no. 1, pp. 79-88, 2011.

[11] L. Lo Muzio, M. D. Mignogna, G. Pannone et al., "Expression of bcl-2 in oral squamous cell carcinoma: an 
immunohistochemical study of 90 cases with clinico-pathological correlations," Oncology Reports, vol. 10, no. 2, pp. 285-291, 2003.

[12] G. Pannone, S. De Maria, R. Zamparese et al., "Prognostic value of human telomerase reverse transcriptase gene expression in oral carcinogenesis," International Journal of Oncology, vol. 30, no. 6, pp. 1349-1357, 2007.

[13] P. Somma, L. Lo Muzio, G. Mansueto et al., "Squamous cell carcinoma of the lower lip: FAS/FASL expression, lymphocyte subtypes and outcome," International Journal of Immunopathology and Pharmacology, vol. 18, no. 1, pp. 59-64, 2005.

[14] C. M. Bandeira, A. A. de Almeida, C. F. L. Carta et al., "Tobacco influence in heavy metals levels in head and neck cancer cases," Environmental Science and Pollution Research, vol. 27, no. 25, pp. 27650-27656, 2018.

[15] S. Ricci, F. Pinto, A. Auletta et al., "The enigmatic role of matrix metalloproteinases in epithelial-to-mesenchymal transition of oral squamous cell carcinoma: implications and nutraceutical aspects," Journal of Cellular Biochemistry, vol. 120, no. 5, pp. 6813-6819, 2019.

[16] P. Pedata, M. Boccellino, R. La Porta et al., "Interaction between combustion-generated organic nanoparticles and biological systems: in vitrostudy of cell toxicity and apoptosis in human keratinocytes," Nanotoxicology, vol. 6, no. 4, pp. 338-352, 2012.

[17] M. Caraglia, M. Marra, G. Giuberti et al., "Theophyllineinduced apoptosis is paralleled by protein kinase a-dependent tissue transglutaminase activation in cancer cells," Journal of Biochemistry, vol. 132, no. 1, pp. 45-52, 2002.

[18] M. Di Domenico, G. Giovane, S. Kouidhi et al., "HPV epigenetic mechanisms related to oropharyngeal and cervix cancers," Cancer Biology \& Therapy, vol. 19, no. 10, pp. 850-857, 2018.

[19] A. Mantovani, A. Ponzetta, A. Inforzato, and S. Jaillon, "Innate immunity, inflammation and tumour progression: double-edged swords," Journal of Internal Medicine, vol. 285, no. 5, pp. 524-532, 2019.

[20] M. Di Domenico, A. Santoro, C. Ricciardi et al., "Epigenetic fingerprint in endometrial carcinogenesis: the hypothesis of a uterine field cancerization," Cancer Biology and Theraphy, vol. 12, no. 5, pp. 447-457, 2011.

[21] A. Mantovani, "The inflammation-cancer connection," The FEBS Journal, vol. 285, no. 4, pp. 638-640, 2018.

[22] T. N. Mayadas, X. Cullere, and C. A. Lowell, "The multifaceted functions of neutrophils," Annual Review of $\mathrm{Pa}$ thology: Mechanisms of Disease, vol. 9, no. 1, pp. 181-218, 2014.

[23] A. Rizzo, A. Losacco, C. R. Carratelli, M. D. Domenico, and N. Bevilacqua, "Lactobacillus plantarum reduces Streptococcus pyogenes virulence by modulating the IL-17, IL-23 and Toll-like receptor 2/4 expressions in human epithelial cells," International Immunopharmacology, vol. 17, no. 2, pp. 453-461, 2013.

[24] V. Papayannopoulos, "Neutrophil extracellular traps in immunity and disease," Nature Reviews Immunology, vol. 18, no. 2, pp. 134-147, 2018.

[25] W. M. Nauseef and N. Borregaard, "Neutrophils at work," Nature Immunology, vol. 15, no. 7, pp. 602-611, 2014.

[26] M. G. Netea, L. A. Joosten, E. Latz et al., "Trained immunity: a program of innate immune memory in health and disease," Science, vol. 352, no. 6284, Article ID aaf1098, 2016.
[27] F. Balkwill and A. Mantovani, "Inflammation and cancer: back to Virchow?" The Lancet, vol. 9255, no. 357, pp. 539545,2001

[28] C. A. Martey, S. J. Pollock, C. K. Turner et al., "Cigarette smoke induces cyclooxygenase- 2 and microsomal prostaglandin E2 synthase in human lung fibroblasts: implications for lung inflammation and cancer," American Journal of Physiology-Lung Cellular and Molecular Physiology, vol. 287, no. 5, pp. 981-991, 2004.

[29] R. M. Peek Jr. and J. E. Crabtree, "Helicobacter infection and gastric neoplasia," The Journal of Pathology, vol. 208, no. 2, pp. 233-248, 2006.

[30] P. E. Castle, S. L. Hillier, L. K. Rabe et al., "An association of cervical inflammation with high-grade cervical neoplasia in women infected with oncogenic human papillomavirus (HPV)," Cancer Epidemiology, Biomarkers and Prevention, vol. 10, no. 10, pp. 1021-1027, 2001.

[31] B. V. Offersen, M. M. Knap, N. Marcussen, M. R. Horsman, S. Hamilton-Dutoit, and J. Overgaard, "Intense inflammation in bladder carcinoma is associated with angiogenesis and indicates good prognosis," British Journal of Cancer, vol. 87, no. 12, pp. 1422-1430, 2002.

[32] G. Garcea, A. R. Dennison, W. P. Steward, and D. P. Berry, "Role of inflammation in pancreatic carcinogenesis and the implications for future therapy," Pancreatology, vol. 5, no. 6, pp. 514-529, 2005.

[33] P. A. Vagefi and W. E. Longo, "Colorectal cancer in patients with inflammatory bowel disease," Clinical Colorectal Cancer, vol. 4, no. 5, pp. 313-319, 2005.

[34] A. Mantovani, P. Allavena, A. Sica, and F. Balkwill, "Cancerrelated inflammation," Nature, vol. 454, no. 7203, pp. 436444, 2008.

[35] B. B. Aggarwal, S. Shishodia, S. K. Sandur, M. K. Pandey, and G. Sethi, "Inflammation and cancer: how hot is the link?" Biochemical Pharmacology, vol. 72, no. 11, pp. 1605-1621, 2006.

[36] A. Fiorelli, S. Ricci, A. Feola et al., "Matrix metalloproteinase- 9 and tissue inhibitor of metalloproteinase- 1 in diagnosis of pleural effusion of malignant origin," Interactive CardioVascular and Thoracic Surgery, vol. 22, no. 4, pp. 411-418, 2016.

[37] A. Santoro, P. Bufo, G. Russo et al., "Expression and clinical implication of cyclooxygenase-2 and E-cadherin in oral squamous cell carcinomas," Cancer Biology and Therapy, vol. 2015, Article ID 26218314, 2015.

[38] B. B. Aggarwal, "Nuclear factor- $\kappa$ B," Cancer Cell, vol. 6, no. 3, pp. 203-208, 2004.

[39] S. Shishodia and B. B. Aggarwal, "Nuclear factor- $\kappa$ B: a friend or a foe in cancer?" Biochemical Pharmacology, vol. 68, no. 6, pp. 1071-1080, 2004.

[40] B. B. Aggarwal, "Signalling pathways of the TNF superfamily: a double-edged sword," Nature Reviews Immunology, vol. 3, no. 9, pp. 745-756, 2003.

[41] F. Balkwill, "Tumor necrosis factor or tumor promoting factor?" Cytokine \& Growth Factor Reviews, vol. 13, no. 2, pp. 135-141, 2002.

[42] A. Devin, A. Cook, Y. Lin, Y. Rodriguez, M. Kelliher, and Z.-g. Liu, "The distinct roles of TRAF2 and RIP in IKK activation by TNF-R1," Immunity, vol. 12, no. 4, pp. 419-429, 2000.

[43] J. Yang, Y. Lin, Z. Guo et al., "The essential role of MEKK3 in TNF-induced NF- $\kappa$ B activation," Nature Immunology, vol. 2, no. 7, pp. 620-624, 2001. 
[44] M. Karin, Y. Yamamoto, and Q. M. Wang, "The IKK NF- $\kappa$ B system: a treasure trove for drug development," Nature Reviews Drug Discovery, vol. 3, no. 1, pp. 17-26, 2004.

[45] A. Lin and B. Dibling, "The true face of JNK activation in apoptosis," Aging Cell, vol. 1, no. 2, pp. 112-116, 2002.

[46] X. Wang and Y. Lin, "Tumor necrosis factor and cancer, buddies or foes?" Acta Pharmacologica Sinica, vol. 29, no. 11, pp. 1275-1288, 2008.

[47] C. D. Woodworth, E. McMullin, M. Iglesias, and G. D. Plowman, "Interleukin 1 alpha and tumor necrosis factor alpha stimulate autocrine amphiregulin expression and proliferation of human papillomavirus-immortalized and carcinoma-derived cervical epithelial cells," Proceedings of the National Academy of Sciences, vol. 92, no. 7, pp. 2840-2844, 1995.

[48] A. Arlt, J. Vorndamm, S. Müerköster et al., "Autocrine production of interleukin lbeta confers constitutive nuclear factor kappaB activity and chemoresistance in pancreatic carcinoma cell lines," Cancer Research, vol. 62, no. 3, pp. 910-916, 2002.

[49] B. Klein, X. Zhang, M. Jourdan et al., "Paracrine rather than autocrine regulation of myeloma-cell growth and differentiation by interleukin-6," Blood, vol. 73, no. 2, pp. 517-526, 1989.

[50] N. Voorzanger, R. Touitou, E. Garcia et al., "Interleukin (IL)10 and IL-6 are produced in vivo by non-Hodgkin's lymphoma cells and act as cooperative growth factors," Cancer Research, vol. 56, no. 23, pp. 5499-5505, 1996.

[51] M. Okamoto, H. Kawamata, K. Kawai, and R. Oyasu, "Enhancement of transformation in vitro of a nontumorigenic rat urothelial cell line by interleukin 6," Cancer Research, vol. 55, no. 20, pp. 4581-4585, 1995.

[52] S. Landi, V. Moreno, L. Gioia-Patricola et al., "Association of common polymorphisms in inflammatory genes interleukin (IL)6, IL8, tumor necrosis factor alpha, NFKB1, and peroxisome proliferator-activated receptor gamma with colorectal cancer," Cancer Research, vol. 63, no. 13, pp. 3560-3566, 2003.

[53] L. S. Angelo, M. Talpaz, and R. Kurzrock, "Autocrine interleukin- 6 production in renal cell carcinoma: evidence for the involvement of p53," Cancer Research, vol. 62, no. 3, pp. 932-940, 2002.

[54] M. Luca, S. Huang, J. E. Gershenwald, R. K. Singh, R. Reich, and M. Bar-Eli, "Expression of interleukin- 8 by human melanoma cells up-regulates MMP-2 activity and increases tumor growth and metastasis," The American Journal of Pathology, vol. 151, no. 4, pp. 1105-1113, 1997.

[55] S. Huang, L. Mills, B. Mian et al., "Fully humanized neutralizing antibodies to interleukin-8 (ABX-IL8) inhibit angiogenesis, tumor growth, and metastasis of human melanoma," The American Journal of Pathology, vol. 161, no. 1, pp. 125-134, 2002.

[56] L. Xu and I. J. Fidler, "Acidic pH-induced elevation in interleukin 8 expression by human ovarian carcinoma cells," Cancer Research, vol. 60, no. 16, pp. 4610-4616, 2000.

[57] I. F. Charo and R. M. Ransohoff, "The many roles of chemokines and chemokine receptors in inflammation," New England Journal of Medicine, vol. 354, no. 6, pp. 610-621, 2006.

[58] L. Feller, M. Altini, and J. Lemmer, "Inflammation in the context of oral cancer," Oral Oncology, vol. 49, no. 9, pp. 887-892, 2013.
[59] J. Lemmer and M. Shear, "Oral submucous fibrosis. A possible case in a person of Caucasian descent," British Dental Journal, vol. 122, no. 8, pp. 343-346, 1967.

[60] R. Rajendran, "Oral submucous fibrosis: etiology, pathogenesis, and future research," Bulletin of the World Health Organization, vol. 72, no. 6, pp. 985-996, 1994.

[61] P. Rajalalitha and S. Vali, "Molecular pathogenesis of oral submucous fibrosis-a collagen metabolic disorder," Journal of Oral Pathology and Medicine, vol. 34, no. 6, pp. 321-328, 2005.

[62] C. P. Chiang, H. Y. Wu, B. Y. Liu, J. T. Wang, and M. Y. P. Kuo, "Quantitative analysis of immunocompetent cells in oral submucous fibrosis in Taiwan," Oral Oncology, vol. 38, no. 1, pp. 56-63, 2002.

[63] C.-J. Chiu, C.-P. Chiang, M.-L. Chang et al., "Association between genetic polymorphism of tumor necrosis factor-a and risk of oral submucous fibrosis, a pre-cancerous condition of oral cancer," Journal of Dental Research, vol. 80, no. 12, pp. 2055-2059, 2001.

[64] S. Khan, S. Prashanth, P. Rao, L. Chatra, and K. M. Veena, "Pathogenesis of oral submucous fibrosis," Journal of Cancer Research and Therapeutics, vol. 8, no. 2, pp. 199-203, 2012.

[65] J.-H. Jeng, Y.-J. Wang, B.-L. Chiang et al., "Roles of keratinocyte inflammation in oral cancer: regulating the prostaglandin $\mathrm{E}_{2}$, interleukin- 6 and TNF- production of oral epithelial cells by areca nut extract and arecoline," Carcinogenesis, vol. 24, no. 8, pp. 1301-1315, 2003.

[66] U. Mattsson, M. Jontell, and P. Holmstrup, "Oral lichen planus and malignant transformation: is a recall of patients justified?" Critical Reviews in Oral Biology \& Medicine, vol. 13, no. 5, pp. 390-396, 2002.

[67] M. Gonzalez-Moles, C. Scully, and J. Gil-Montoya, "Oral lichen planus: controversies surrounding malignant transformation," Oral Diseases, vol. 14, no. 3, pp. 229-243, 2008.

[68] C. Scully, M. Beyli, M. C. Ferreiro et al., "Update on oral lichen planus: etiopathogenesis and management," Critical Reviews in Oral Biology \& Medicine, vol. 9, no. 1, pp. 86-122, 1998.

[69] M. D. Mignogna, S. Fedele, L. Lo Russo, L. Lo Muzio, and E. Bucci, "Immune activation and chronic inflammation as the cause of malignancy in oral lichen planus: is there any evidence ?" Oral Oncology, vol. 40, no. 2, pp. 120-130, 2004.

[70] T.-J. Li and J. Cui, "COX-2, MMP-7 expression in oral lichen planus and oral squamous cell carcinoma," Asian Pacific Journal of Tropical Medicine, vol. 6, no. 8, pp. 640-643, 2013.

[71] S. J. Hooper, M. J. Wilson, and S. J. Crean, "Exploring the link between microorganisms and oral cancer: a systematic review of the literature," Head \& Neck, vol. 31, no. 9, pp. 1228-1239, 2009.

[72] M. Bloching, W. Reich, J. Schubert, T. Grummt, and A. Sandner, "The influence of oral hygiene on salivary quality in the Ames test, as a marker for genotoxic effects," Oral Oncology, vol. 43, no. 9, pp. 933-939, 2007.

[73] A. Migliaccio, M. D. Domenico, S. Green et al., "Phosphorylation on tyrosine of in Vitro Synthesized human estrogen receptor activates its hormone binding," Molecular Endocrinology, vol. 3, no. 7, pp. 1061-1069, 1989.

[74] R. L. Cooper and R. J. Kavlock, "Endocrine disruptors and reproductive development: a weight-of-evidence overview," Journal of Endocrinology, vol. 152, no. 2, pp. 159-166, 1997.

[75] F. Auricchio, M. Di Domenico, A. Migliaccio, G. Castoria, and A. Bilancio, "The role of estradiol receptor in the proliferative activity of vanadate on MCF-7 cells," Cell Growth and Differentiation, vol. 6, no. 2, pp. 105-113, 1995. 
[76] M. Boccellino, D. Di Stasio, G. Dipalma et al., "Steroids and growth factors in oral squamous cell carcinoma: useful source of dental-derived stem cells to develop a steroidogenic model in new clinical strategies," European Review for Medical and Pharmacological Sciences, vol. 23, no. 20, pp. 8730-8740, 2019.

[77] A. Migliaccio, M. Di Domenico, G. Castoria et al., "Steroid receptor regulation of epidermal growth factor signaling through Src in breast and prostate cancer cells: steroid antagonist action," Cancer Research, vol. 65, no. 22, pp. 10585-10593, 2005.

[78] A. Migliaccio, G. Castoria, M. D. Domenico et al., "Crosstalk between EGFR and extranuclear steroid receptors," Annals of the New York Academy of Sciences, vol. 1089, no. 1, pp. 194-200, 2006.

[79] S. Sieri, V. Krogh, G. Bolelli et al., "Sex hormone levels, breast cancer risk, and cancer receptor status in postmenopausal women: the ORDET cohort," Cancer Epidemiology Biomarkers \& Prevention, vol. 18, no. 1, pp. 169-176, 2009.

[80] A. Feola, S. Ricci, S. Kouidhi et al., "Multifaceted breast cancer: the molecular connection with obesity," Journal of Cellular Physiology, vol. 232, no. 1, pp. 69-77, 2017.

[81] L. Varricchio, A. Migliaccio, G. Castoria et al., "Inhibition of estradiol receptor/src association and cell growth by an estradiol receptor tyrosine-phosphorylated peptide," Molecular Cancer Research, vol. 5, no. 11, pp. 1213-1221, 2007.

[82] S. R. Hammes, "The further redefining of steroid-mediated signaling," Proceedings of the National Academy of Sciences, vol. 100 , no. 5 , pp. $2168-2170,2003$.

[83] T. J. Key, "Hormones and cancer in humans," Mutation Research, vol. 333, no. 1-2, pp. 59-67, 1995.

[84] M. Boccellino, L. Quagliuolo, A. Verde et al., "In vitro model of stromal and epithelial immortalized endometriotic cells," Journal of Cellular Biochemistry, vol. 113, no. 4, pp. 12921301, 2012.

[85] J. Russo and I. H. Russo, "The role of estrogen in the initiation of breast cancer," Journal of Steroid Biochemistry and Molecular Biology, vol. 102, no. 1-5, pp. 89-96, 2006.

[86] A. Migliaccio, G. Castoria, A. de Falco et al., "In vitro phosphorylation and hormone binding activation of the synthetic wild type human estradiol receptor," The Journal of Steroid Biochemistry and Molecular Biology, vol. 38, no. 4, pp. 407-413, 1991.

[87] W. Yue, J.-P. Wang, Y. Li et al., "Effects of estrogen on breast cancer development: role of estrogen receptor independent mechanisms," International Journal of Cancer, vol. 127, no. 8, pp. 1748-1757, 2010.

[88] D. A. Altomare and J. R. Testa, "Perturbations of the AKT signaling pathway in human cancer," Oncogene, vol. 24, no. 50, pp. 7455-7464, 2005.

[89] E. Di Zazzo, A. Feola, C. Zuchegna et al., "The p85 regulatory subunit of PI3K mediates cAMP-PKA and insulin biological effects on MCF-7 cell growth and motility," The Scientific World Journal, vol. 2014, Article ID 565839, 11 pages, 2014.

[90] A. Feola, A. Cimini, F. Migliucci et al., "The inhibition of p $85 \alpha$ PI3KSer83 phosphorylation prevents cell proliferation and invasion in prostate cancer cells," Journal of Cellular Biochemistry, vol. 114, no. 9, pp. 2114-2119, 2013.

[91] C. Cosentino, M. Di Domenico, A. Porcellini et al., "p85 regulatory subunit of PI3K mediates cAMP-PKA and estrogens biological effects on growth and survival," Oncogene, vol. 26, no. 14, pp. 2095-2103, 2007.

[92] B. S. Jaiswal, V. Janakiraman, N. M. Kljavin et al., "Somatic mutations in $\mathrm{p} 85 \alpha$ promote tumorigenesis through class IA
PI3K activation," Cancer Cell, vol. 16, no. 6, pp. 463-474, 2009.

[93] W. Elis, E. Lessmann, M. Oelgeschlager, and M. Huber, "Mutations in the inter-SH2 domain of the regulatory subunit of phos-phoinositide 3-kinase: effects on catalytic subunit binding and holoenzyme function," Biological Chemistry, vol. 387, no. 12, pp. 1567-1573, 2006.

[94] G. De Gregorio, A. Coppa, C. Cosentino et al., "The p85 regulatory subunit of PI3K mediates TSH-cAMP-PKA growth and survival signals," Oncogene, vol. 26, no. 14, pp. 2039-2047, 2007.

[95] D. King, D. Yeomanson, and H. E. Bryant, "PI3King the lock," Journal of Pediatric Hematology/Oncology, vol. 37, no. 4, pp. 245-251, 2015.

[96] J. Peltier, A. O’Neill, and D. V. Schaffer, "PI3K/Akt and CREB regulate adult neural hippocampal progenitor proliferation and differentiation," Developmental Neurobiology, vol. 67, no. 10, pp. 1348-1361, 2007.

[97] V. A. Rafalski and A. Brunet, "Energy metabolism in adult neural stem cell fate," Progress in Neurobiology, vol. 93, no. 2, pp. 182-203, 2011.

[98] J. Raphael, D. Desautels, K. I. Pritchard, E. Petkova, and P. S. Shah, "Phosphoinositide 3-kinase inhibitors in advanced breast cancer: a systematic review and meta-analysis," European Journal of Cancer, vol. 91, pp. 38-46, 2018.

[99] G. Castoria, A. Migliaccio, L. D’Amato et al., "Integrating signals between cAMP and MAPK pathways in breast cancer," Frontiers in Bioscience, vol. 13, no. 13, p. 1318, 2008.

[100] Y.-R. Lee, J. Park, H.-N. Yu, J.-S. Kim, H. J. Youn, and S. H. Jung, "Up-regulation of PI3K/Akt signaling by $17 \beta$ estradiol through activation of estrogen receptor- $\alpha$, but not estrogen receptor- $\beta$, and stimulates cell growth in breast cancer cells," Biochemical and Biophysical Research Communications, vol. 336, no. 4, pp. 1221-1226, 2005.

[101] C. F. Donini, E. Di Zazzo, C. Zuchegna et al., "The p85 $\alpha$ regulatory subunit of PI3K mediates cAMP-PKA and retinoic acid biological effects on MCF7 cell growth and migration," International Journal of Oncology, vol. 40, no. 5, pp. 1627-1635, 2012.

[102] W. Gong, Y. Xiao, Z. Wei et al., "Toward the use of precision medicine for the treatment of head and neck squamous cell carcinoma," Oncotarget, vol. 8, no. 2, pp. 2141-2152, 2017.

[103] A. Grimaldi, D. Santini, S. Zappavigna et al., "Antagonistic effects of chloroquine on autophagy occurrence potentiate the anticancer effects of everolimus on renal cancer cells," Cancer Biology \& Therapy, vol. 16, no. 4, pp. 567-579, 2015.

[104] A. Fiorelli, G. Vicidomini, M. Di Domenico et al., "Vascular endothelial growth factor in pleural fluid for differential diagnosis of benign and malignant origin and its clinical applications," Interactive CardioVascular and Thoracic Surgery, vol. 12, no. 3, pp. 420-424, 2011.

[105] A. Bohra and S. Bhateja, "Carcinogenesis and sex hormones: a review," Endocrinology and Metabolic Syndrome, vol. 4, no. 1, pp. 1-14, 2015.

[106] M. H. Parkar, H. N. Newman, and I. Olsen, "Polymerase chain reaction analysis of oestrogen androgen receptor expression in human ginigival and periodontal tissue," Archives of Oral Biology, vol. 41, pp. 979-983, 1982.

[107] G. Colella, G. Izzo, F. Carinci et al., "Expression of sexual hormones receptors in oral squamous cell carcinoma," International Journal of Immunopathology and Pharmacology, vol. 24, no. 2_suppl, pp. 129-132, 2011. 
[108] L. Mannarini and V. Kratochvil, "Human papiloma virus in head \& neck region: a review of literature," ACTA Otorhinolaryngologica Italica, vol. 29, pp. 119-126, 2009.

[109] C. Y. Fan and M. F. Malhelm, "Expression of androgen receptors, epidermal growth factor receptor \& transforming growth factor alpha in salivary duct carcinoma," Archives of Otolaryngology-Head and Neck Surgery, vol. 127, pp. 1095-1097, 2001.

[110] S. M. Nasser, W. C. Faquin, and Y. Dayal, "Expression of androgen, estrogen, and progesterone receptors in salivary gland tumors," American Journal of Clinical Pathology, vol. 119, no. 6, pp. 801-806, 2003.

[111] D. R. Ciocca, L. A. Puy, and L. C. Fasoli, "Study of estrogen receptor, progesterone receptor, and the estrogen-regulated Mr 24,000 protein in patients with carcinomas of the endometrium and cervix," Cancer Research, vol. 49, no. 15, pp. 4298-4304, 1989.

[112] H.-R. Lee, T.-H. Kim, and K.-C. Choi, "Functions and physiological roles of two types of estrogen receptors, ER $\alpha$ and ER $\beta$, identified by estrogen receptor knockout mouse," Laboratory Animal Research, vol. 28, no. 2, pp. 71-76, 2012.

[113] R. T. Falk, L. A. Brinton, J. F. Dorgan et al., "Relationship of serum estrogens and estrogen metabolites to postmenopausal breast cancer risk: a nested case-control study," Breast Cancer Research, vol. 15, p. R34, 2013.

[114] J. K. Timothy, E. A. Naomi, and K. V. Pia, "Macronutrient metabolism group symposium on "Energy flux and cancer," Energy balance and cancer: the role of sex hormones," Proceedings of the Nutrition Society, vol. 60, pp. 81-89, 2001.

[115] P. Nainani, N. Nagpal, M. Agrawal, and A. Paliwal, "Sex hormones in gender-specific risk for head and neck cancer: a review," Journal of International Society of Preventive and Community Dentistry, vol. 4, no. 4, pp. 1-4.

[116] O. J. Cordero and R. Varela-Calviño, "Oral hygiene might prevent cancer," Heliyon, vol. 4, no. 10, Article ID e00879, 2018.

[117] N. Sardaro, F. Della Vella, M. A. Incalza et al., "Oxidative stress and oral mucosal diseases: an overview," In Vivo, vol. 33, no. 2, pp. 289-296, 2019.

[118] M. Tatullo, M. Marrelli, S. Scacco et al., "Relationship between oxidative stress and "burning mouth syndrome" in female patients: a scientific hypothesis," Europian Review for Medical Pharmacological Science, vol. 16, no. 9, pp. 12181221, 2012.

[119] M. Boccellino, D. Di Stasio, R. Serpico et al., "Analysis of saliva samples in patients with Prader-Willi syndrome," Journal of Biological Regulators and Homeostatic Agents, vol. 32, no. 2, pp. 107-111, 2018.

[120] M. Boccellino, F. Cuccovillo, M. Napolitano et al., "Styrene7,8-oxide activates a complex apoptotic response in neuronal PC12 cell line," Carcinogenesis, vol. 24, no. 3, pp. 535-540, 2003.

[121] A. Ballini, L. Santacroce, S. Cantore et al., "Probiotics efficacy on oxidative stress values in inflammatory bowel disease: a randomized double-blinded placebo-controlled pilot study," Endocrine, Metabolic \& Immune Disorders-Drug Targets, vol. 19, no. 3, pp. 373-381, 2019.

[122] F. Inchingolo, M. Marrelli, S. Annibali et al., "Influence of endodontic treatment on systemic oxidative stress," International Journal of Medical Science, vol. 11, no. 1, pp. 1-6, 2013.

[123] M. Contaldo, D. Di Stasio, M. Petruzzi, R. Serpico, and A. Lucchese, "In vivo reflectance confocal microscopy of oral lichen planus," International Journal of Dermatology, vol. 58, no. 8, pp. 940-945, 2019.

[124] A. Romano, M. Contaldo, F. Della Vella et al., "Topical toluidine blue-mediated photodynamic therapy for the treatment of oral lichen planus," Journal of Biological Regulators and Homeostatic Agents, vol. 33, no. 3, pp. 27-33, 2019.

[125] F. della Vella, D. Lauritano, C. Lajolo et al., "The Pseudolesions of the oral mucosa: differential diagnosis and related systemic conditions," Applied Science, vol. 12, no. 9, p. 412, 2019.

[126] A. Fiorelli, M. Accardo, E. Carelli, D. Angioletti, M. Santini, and M. Di Domenico, "Circulating tumor cells in diagnosing lung cancer: clinical and morphologic analysis," The Annals of Thoracic Surgery, vol. 99, no. 6, pp. 1899-1905, 2015.

[127] Y. A. Chang, S. L. Weng, S. F. Yang et al., "A threemicroRNA signature as a potential biomarker for the early detection of oral cancer," International Journal of Molecular Sciences, vol. 19, no. 3, p. 758, 2018.

[128] M. Lamberti, R. Capasso, A. Lombardi et al., "Two different serum MiRNA signatures correlate with the clinical outcome and histological subtype in pleural malignant mesothelioma patients," PLoS One, vol. 10, no. 8, Article ID e0135331, 2015.

[129] D. P. Bartel, "MicroRNAs: target recognition and regulatory functions," Cell, vol. 136, no. 2, pp. 215-233, 2009.

[130] M. Boccellino, D. Vanacore, S. Zappavigna et al., "Testicular cancer from diagnosis to epigenetic factors," Oncotarget, vol. 8, no. 61, pp. 104654-104663, 2017.

[131] D. Vanacore, M. Boccellino, S. Rossetti et al., "Micrornas in prostate cancer: an overview," Oncotarget, vol. 8, no. 30, pp. 50240-50251, 2017.

[132] P. Gholizadeh, H. Eslami, M. Yousefi, M. Asgharzadeh, M. Aghazadeh, and H. S. Kafil, "Role of oral microbiome on oral cancers, a review," Biomedicine \& Pharmacotherapy, vol. 84, pp. 552-558, 2016.

[133] M. Contaldo, A. Romano, M. Mascitti et al., "Association between denture stomatitis, candida species and diabetic status," Journal of Biological Regulators and Homeostatic Agents, vol. 33, pp. 35-41, 2019.

[134] D. Lauritano, G. Moreo, F. Carinci et al., "An observational study of characteristics and prevalence of oral diseases in an Italian cohort," International Journal of Environmental Research and Public Health, vol. 16, no. 19, Article ID E3763, 2019.

[135] M. Petruzzi, F. Della Vella, A. Cassandro et al., "Dorsal tongue porphyrin autofluorescence and Candida saprophytism: a prospective observational study," PLoS One, vol. 14, no. 9, Article ID e0223072, 2019.

[136] F. Inchingolo, G. Dipalma, N. Cirulli et al., "Microbiological results of improvement in periodontal condition by administration of oral probiotics," Journal of Biological Regulators and Homeostatic Agents, vol. 32, no. 5, pp. 1323-1328, 2018.

[137] L. Zhang, Y. Liu, H. J. Zheng, and C. P. Zhang, "The oral microbiota may have influence on oral cancer," Frontiers in Cellular and Infection Microbiology, vol. 9, p. 476, 2020.

[138] P. Holmstrup, C. Damgaard, I. Olsen et al., "Comorbidity of periodontal disease: two sides of the same coin? An introduction for the clinician," Journal of Oral Microbiology, vol. 9, no. 1, Article ID 1332710, 2017.

[139] A. Hugoson and O. Norderyd, "Has the prevalence of periodontitis changed during the last 30 years?" Journal of Clinical Periodontology, vol. 35, no. 8, pp. 338-345, 2008. 
[140] S. A. Hienz, S. Paliwal, and S. Ivanovski, "Mechanisms of bone resorption in periodontitis," Journal of Immunology Research, vol. 2015, Article ID 26065002, 10 pages, 2015.

[141] A. Mombelli, "Microbial colonization of the periodontal pocket and its significance for periodontal therapy," Periodontology 2000, vol. 76, no. 1, pp. 85-96, 2018.

[142] P. I. Eke, B. A. Dye, L. Wei, G. O. Thornton-Evans, and R. J. Genco, "Prevalence of periodontitis in adults in the United States: 2009 and 2010," Journal of Dental Research, vol. 91, no. 10, pp. 914-920, 2012.

[143] M. Ninomiya, M. Hashimoto, K. Yamanouchi, Y. Fukumura, T. Nagata, and K. Naruishi, "Relationship of oral conditions to the incidence of infective endocarditis in periodontitis patients with valvular heart disease: a cross-sectional study," Clinical Oral Investigations, vol. 24, no. 2, pp. 833-840, 2020.

[144] A. Ballini, S. Cantore, D. Farronato et al., "Periodontal disease and bone pathogenesis: the crosstalk between cytokines and porphyromonasgingivalis," Journal of Biological Regulators and Homeostatic Agents, vol. 29, no. 2, pp. 273281, 2015.

[145] M. Contaldo, C. Lajolo, M. Di Petrillo et al., "Analysis of lip pigmentations by reflectance confocal microscopy: report of two cases," Journal of Biological Regulators and Homeostatic Agents, vol. 33, no. 3, pp. 19-25, 2019.

[146] C. Salerno, M. Pascale, M. Contaldo et al., "Candida-associated denture stomatitis," Medicina Oral, Patología Oral Y Cirugía Bucal, vol. 16, no. 2, pp. 139-143, 2011.

[147] L. Togni, M. Mascitti, A. Santarelli et al., "Unusual conditions impairing saliva secretion: developmental anomalies of salivary glands," Frontiers in Physiology, vol. 10, p. 855, 2019.

[148] A. Rizzo, M. D. Domenico, C. R. Carratelli, and R. Paolillo, "The role of Chlamydia and Chlamydophila infections in reactive arthritis," Internal Medicine, vol. 51, no. 1 , pp. 113-117, 2012.

[149] A. Rizzo, M. Di Domenico, C. R. Carratelli, N. Mazzola, and R. Paolillo, "Induction of proinflammatory cytokines in human osteoblastic cells by Chlamydia pneumoniae," $C y$ tokine, vol. 56, no. 2, pp. 450-457, 2011.

[150] S. Pesee and T. Arpornsuwan, "Salivary cytokine profile in elders with Candida-related denture stomatitis," Gerodontology, vol. 32, no. 2, pp. 132-140, 2015.

[151] I. Paoletti, A. Fusco, E. Grimaldi et al., "Assessment of host defence mechanisms induced by Candida species," International Journal of Immunopathology and Pharmacology, vol. 26, no. 3, pp. 663-672, 2013.

[152] Z. Heidari, B. Moudi, and H. Mahmoudzadeh-Sagheb, "Immunomodulatory factors gene polymorphisms in chronic periodontitis: an overview," BMC Oral Health, vol. 19, no. 1, p. 29, 2019.

[153] M. Di Domenico, G. M. Pierantoni, and A. Feola, "Prognostic significance of $\mathrm{N}$-Cadherin expression in oral squamous cell carcinoma," Anticancer Research, vol. 31, no. 12, pp. 4211-4218, 2011.

[154] M. Boccellino, G. Camussi, A. Giovane et al., "Platelet-activating factor regulates cadherin-catenin adhesion system expression and $\beta$-catenin phosphorylation during kaposi's sarcoma cell motility," The American Journal of Pathology, vol. 166, no. 5, pp. 1515-1522, 2005.

[155] G. Giannelli, L. Milillo, F. Marinosci et al., "Altered expression of integrins and basement membrane proteins in malignant and pre-malignant lesions of oral mucosa," Journal of Biological Regulators and Homeostatic Agents, vol. 15, no. 4, pp. 375-380, 2001.
[156] L. Lo Muzio, G. Campisi, A. Farina et al., "P-cadherin expression and survival rate in oral squamous cell carcinoma: an immunohistochemical study," BMC Cancer, vol. 5, p. 63, 2005.

[157] L. Lo Muzio, G. Pannone, S. Staibano et al., "p120cat delocalization in cell lines of oral cancer," Oral Oncology, vol. 38, no. 1, pp. 64-72, 2002.

[158] W. T. Loo, L. Jin, M. N. Cheung, M. Wang, and L. W. Chow, "Epigenetic change in E-cadherin and COX-2 to predict chronic periodontitis," Journal of Translational Medicine, vol. 8, Article ID 110, 2010.

[159] M. Ianni, G. Bruzzesi, D. Pugliese et al., "Variations in inflammatory genes are associated with periodontitis," Immunity and Ageing, vol. 10, no. 1, Article ID 24274085, 2013.

[160] G. Pannone, A. Santoro, A. Feola et al., "The role of E-cadherin down-regulation in oral cancer: $\mathrm{CDH} 1$ gene expression and epigenetic blockage," Current Cancer Drug Targets, vol. 14, no. 2, pp. 115-127, 2014.

[161] C. P. Rudick, M. S. Lang, and T. Miyamoto, "Understanding the pathophysiology behind chairside diagnostics and genetic testing for IL-1 and IL-6," Oral Diseases, vol. 25, no. 8, pp. 1879-1885, 2019.

[162] M. L. Marazita, J. A. Burmeister, J. C. Gunsolley, T. E. Koertge, K. Lake, and H. A. Schenkein, "Evidence for autosomal dominant inheritance and race-specific heterogeneity in early-onset periodontitis," Journal of Periodontology, vol. 65, no. 6, pp. 623-630, 1994.

[163] T. M. Hassell and E. L. Harris, "Genetic influences in caries and periodontal diseases," Critical Reviews in Oral Biology \& Medicine, vol. 6, no. 4, pp. 319-342, 1995.

[164] G. Pannone, P. Bufo, M. F. Caiaffa et al., "Cyclooxygenase-2 expression in oral squamous cell carcinoma," International Journal of Immunopathology and Pharmacology, vol. 17, no. 3, pp. 273-282, 2004.

[165] G. Pannone, F. Sanguedolce, S. De Maria et al., "Cyclooxygenase isozymes in oral squamous cell carcinoma: a realtime RT-PCR study with clinic pathological correlations," International Journal of Immunopathology and Pharmacology, vol. 20, no. 2, pp. 317-324, 2007.

[166] S. Cantore, R. Mirgaldi, A. Ballini et al., "Cytokine gene polymorphisms associate with microbiogical agents in periodontal disease: our experience," International Journal of Medical Sciences, vol. 11, no. 7, pp. 674-679, 2014.

[167] S. R. Diehl, Y. Wang, C. N. Brooks et al., "Linkage disequilibrium of interleukin-1 genetic polymorphisms with early-onset periodontitis," Journal of Periodontology, vol. 70, no. 4, pp. 418-430, 1999.

[168] R. S. Gomez, W. O. Dutra, and P. R. Moreira, "Epigenetics and periodontal disease: future perspectives," Inflammation Research, vol. 58, no. 10, pp. 625-629, 2009.

[169] E. C. Küchler, J. F. Mazzi-Chaves, L. S. Antunes et al., "Current trends of genetics in apical periodontitis research," Brazilian Oral Research, vol. 32, pp. 126-132, 2018.

[170] K. Noda, M. Yamazaki, Y. Iwai et al., "IL- $1 \beta$ and TNF- $\alpha$ regulate mouse amelotin gene transcription in gingival epithelial cells," Journal of Oral Science, vol. 60, no. 3, pp. $388-398,2018$.

[171] A. Wankhede, S. Wankhede, and S. Wasu, "Role of genetic in periodontal disease," Journal of the International Clinical Dental Research Organization, vol. 9, no. 2, pp. 53-58, 2017.

[172] A. Fiorelli, F. Morgillo, M. Fasano et al., "The value of matrix metalloproteinase-9 and vascular endothelial growth factor receptor 1 pathway in diagnosing indeterminate pleural 
effusion," Interactive Cardiovascular and Thoracic Surgery, vol. 16, no. 3, pp. 263-269, 2012.

[173] A. Jain and R. Bahuguna, "Role of matrix metalloproteinases in dental caries, pulp and periapical inflammation: an overview," Journal of Oral Biology and Craniofacial Research, vol. 5, no. 3, pp. 212-218, 2015.

[174] A. Ballini, S. Cantore, S. Scacco et al., "A comparative study on different stemness gene expression between dental pulp stem cells vs. dental bud stem cells," European Review for Medical and Pharmacological Sciences, vol. 23, no. 4, pp. 1626-1633, 2019.

[175] E. Buommino, M. Boccellino, A. De Filippis et al., "3-Omethylfunicone produced bypenicillium pinophilum affects cell motility of breast cancer cells, downregulating $\alpha \mathrm{v} \beta 5$ integrin and inhibiting metalloproteinase-9 secretion," Molecular Carcinogenesis, vol. 46, no. 11, pp. 930-940, 2007.

[176] P. Åström, K. Juurikka, E. S. Hadler-Olsen et al., “The interplay of matrix metalloproteinase-8, transforming growth factor- $\beta 1$ and vascular endothelial growth factor- $C$ cooperatively contributes to the aggressiveness of oral tongue squamous cell carcinoma," British Journal of Cancer, vol. 117, no. 7, pp. 1007-1016, 2017.

[177] M. Contaldo, V. Luzzi, G. Ierardo et al., "Bisphosphonaterelated osteonecrosis of the jaws and dental surgery procedures in children and young people with osteogenesis imperfecta: a systematic review," Journal of Stomatology, Oral and Maxillofacial Surgery, vol. 720 pages, 2020.

[178] D. F. Kinane, H. Shiba, and T. C. Hart, "The genetic basis of periodontitis," Periodontology 2000, vol. 39, pp. 91-117, 2005.

[179] Research, Science and Therapy Committee of American Academy of Periodontology, "Informational paper: implications of genetic technology for the management of periodontal diseases," Journal of Periodontology, vol. 76, no. 5, pp. 850-857, 2005.

[180] F. R. Grassi, F. Ciccolella, G. D’Apolito et al., "Effect of lowlevel laser irradiation on osteoblast proliferation and bone formation," Journal of Biological Regulators and Homeostatic Agents, vol. 25, no. 4, pp. 603-614, 2011.

[181] M. F. Khiyani, M. Ahmadi, J. Barbeau et al., "Salivary biomarkers in denture stomatitis: a systematic review," JDR Clinical \& Translational Research, vol. 4, no. 4, pp. 312-322, 2019.

[182] V. Hirsch, M. Wolgin, A. V. Mitronin, and A. M. Kielbassa, "Inflammatory cytokines in normal and irreversibly inflamed pulps: a systematic review," Archives of Oral Biology, vol. 82, pp. 38-46, 2017.

[183] G. Donnarumma, V. De Gregorio, A. Fusco et al., "Inhibition of HSV-1 replication by laser diode-irradiation: possible mechanism of action," International Journal of Immunopathology and Pharmacology, vol. 23, no. 4, pp. 1167-1176, 2010.

[184] M. F. Coscia, R. Monno, A. Ballini et al., "Human papilloma virus (HPV) genotypesprevalence in a region of southitaly (apulia)," Annali dell'Istituto Superiore di Sanità, vol. 51, no. 3, pp. 248-251, 2015.

[185] M. Boccellino, D. Di Stasio, A. Romano et al., "Lichen planus: molecular pathway and clinical implications in oral disorders," Journal of Biological Regulators and Homeostatic Agents, vol. 32, no. 2, pp. 135-138, 2018.

[186] D. Menditti, L. Laino, M. Milano et al., "Intraoral lymphoepithelial carcinoma of the minor salivary glands," In Vivo, vol. 26, no. 6, pp. 1087-1089, 2012.

[187] G. Pannone, A. Santoro, F. Carinci et al., "Double demonstration of oncogenic high risk human papilloma virus DNA and HPV-E7 protein in oral cancers," International Journal of Immunopathology and Pharmacology, vol. 24, no. 2_suppl, pp. 95-101, 2011.

[188] S. Staibano, L. Lo Muzio, G. Pannone et al., "P53 and hMSH2 expression in basal cell carcinomas and malignant melanomas from photoexposed areas of head and neck region," International Journal of Oncology, vol. 19, no. 3, p. 551-559, 2001.

[189] G. Favia, D. Kanduc, L. Lo Muzio, A. Lucchese, and R. Serpico, "Possible association between HPV16 E7 protein level and cytokeratin 19," International Journal of Cancer, vol. 111, no. 5, pp. 795-797, 2004.

[190] A. M. Cossu, L. Mosca, S. Zappavigna et al., "Long noncoding RNAs as important biomarkers in laryngeal cancer and other head and neck tumours," International Journal of Molecular Sciences, vol. 20, no. 14, p. 3444, 2019

[191] G. Lodi, R. Franchini, S. Warnakulasuriya et al., "Interventions for treating oral leukoplakia to prevent oral cancer," Cochrane Database Systematic Review, vol. 2016, no. 7, Article ID 27471845, 2016.

[192] J. Park, X. Zhang, S. K. Lee et al., "CCL28-induced RAR $\beta$ expression inhibits oral squamous cell carcinoma bone invasion," Journal of Clinical Investigation, vol. 129, no. 12, pp. 5381-5399, 2019.

[193] F. Carinci, M. Martinelli, M. Contaldo et al., "Focus on periodontal disease and development of endocarditis," Journal of Biological Regulators and Homeostatic Agents, vol. 32, no. 2, pp. 143-147, 2018.

[194] I. L. I. de Mendoza, X. M. Mendia, A. M. G. de la Fuente, G. Q. Andrés, and J. M. A. Urizar, "Role of Porphyromonas gingivalis in oral squamous cell carcinoma development: a systematic review," Journal of Periodontal Research, vol. 55, no. 1, pp. 13-22, 2019.

[195] R. Franco, G. Nicoletti, A. Lombardi et al., "Current treatment of cutaneous squamous cancer and molecular strategies for its sensitization to new target-based drugs," Expert Opinion on Biological Therapy, vol. 13, no. 1, pp. 51-66, 2013.

[196] M. Boccellino, C. Alaia, G. Misso et al., "Gene interference strategies as a new tool for the treatment of prostate cancer," Endocrine, vol. 49, no. 3, pp. 588-605, 2015.

[197] M. Romano, F. D. Francesco, G. Pirozzi et al., "Expression of cancer stem cell biomarkers as a tool for a correct therapeutic approach to hepatocellular carcinoma," Oncoscience, vol. 2, no. 5 , p. $443,2015$.

[198] M. Boccellino, F. Pinto, V. Ieluzzi et al., "Proteomics analysis of human serum of patients with non-small-cell lung cancer reveals proteins as diagnostic biomarker candidates," Journal of Cellular Physiology, vol. 234, no. 12, pp. 23798-23806, 2019. 